\title{
The Discussion on the Innovation of Ideological and Political Education Work from the Perspective of Great Ideology and Politics
}

\author{
Yuting Niu \\ Gansu Lanzhou 730050, LANZHOU INSTITUTE OF TECHNOLOGY, China. \\ E-mail:1060505367@qq.com
}

\begin{abstract}
The convening of the conference of national university ideological and political work marks the formal establishment of the strategic positioning and work pattern of our country's "great ideology and politics". Under the vision of great ideology and politics in the national education strategy, the ideological and political education work in colleges and universities should not rest on the traditional teaching idea, but should proceed from the teaching idea, class system, teaching practice, team building and other aspects to actively construct the pattern of "great ideological and political education" and improve the reform and innovation of ideological and political education and teaching in colleges and universities.
\end{abstract}

Keywords: Great ideology and politics; Ideological and political education; Reform; Innovation

\section{Introduction}

Ideological and political education in colleges and universities is a key course to implement the fundamental task fostering virtue through education. To run ideological and political education well, colleges and universities should keep pace with the time, adhere to the "eight unifications" and innovate ideological and political teaching. General Secretary Xi Jinping pointed out at the 2019 ideological and political theory teacher symposium that "To promote the reform and innovation of ideological and political theory courses, it is necessary to continuously enhance the ideological content, theoretical content, affinity and pertinence of ideological and political courses." Therefore, the "great ideological and political" education pattern has become increasingly prominent. Strengthening the reform and innovation of ideological and political education in colleges and universities is the unanimous goal of current college education. In teaching, the "great ideological and political" education concept emphasizes the combination of theoretical teaching and practical teaching, and emphasizes that ideological and political education takes students as the main body, which is conducive to ideological and political education going deeply into the teaching, forming a harmonious unity of ideological and political education and humanistic education, and promoting the comprehensive improvement of students' comprehensive literacy. From the perspective of "great ideology and politics", how to innovate ideology and politics education and accelerate the development of ideological and political teaching is an issue that every university should focus on.

\section{The meaning of great ideology and politics}

"Great ideology and politics" are to respond to the encouragement and call of the central government and relevant departments of the state. On the basis of traditional teaching, it broadens the depth and breadth of teaching, combines classroom teaching with social education, combines theory with practice, integrates ideological and political education into all aspects of students, and enables students to practice the results of ideological and political education through practice. Therefore, the so-called "great ideology and politics" is to break through the limitations of traditional teaching,

Copyright (C) 2020 Yuting Niu

doi: 10.18282/le.v9i5.1198

This is an open-access article distributed under the terms of the Creative Commons Attribution Non-Commercial License

(http://creativecommons.org/licenses/by-nc/4.0/), which permits unrestricted non-commercial use, distribution, and reproduction in any medium, provided the original work is properly cited. 
strengthen ideological and political practice, establish the principal position of students, deepen the connotation of ideological and political education, and infiltrate ideological and political education into every stage of college education. From the perspective of the education, in the education teaching, according to the deficiency existing in traditional education, colleges and universities should reform the innovate the teaching system and the target, teaching content and method, teaching concept and ideas, improve the timeliness and pertinence of ideological and political education, manifest the openness, practicality and humanity of ideological and political education, thus effectively promoting the all-round development of students.

\section{Countermeasures to innovate ideological and political education from the perspective of "great ideology and politics"}

\subsection{Establish the overall consciousness of "great ideology and politics" education in colleges and universities}

Colleges and universities should establish "great ideology and politics" education concept, and infiltrate the ideological and political education into every place. They have to do a good job in the top-level design of ideological and political education, regard every department, every course, every coach in the colleges and universities as educational power of ideological and political education, and build all-round integration management system, which was led by the communist party organization, jointly coordinated by the labor union and youth league, coordinated and followed up by related departments to follow up, actively implemented by the various departments, and the participated by all teachers and students, thus forming the all-round development of management, teaching, scientific research, practice, and education, giving full play to the biggest cultivation effect of each of the education subject, and jointly develop young talents with high quality. In addition, colleges and universities should actively improve the ideological and political education system, such as teaching management system, teaching quality control, incentive mechanism, etc., which enables ideological and political education to have rules to follow, giving full play to the "great ideology and politics" pattern, and improving the quality of ideological and political education in colleges and universities.

\subsection{Improve the teaching method of ideological and political education in colleges and universities}

Under the background of "great ideology and politics", ideological and political education is divided into the first class and the second class. The first class of ideological and political education is the basis of theoretical knowledge. In the teaching system, colleges and universities should improve the content of ideological and political courses and integrate socialist core values, traditional and excellent Chines culture, and red revolutionary culture into the teaching system. The course setting should be targeted. It is necessary to divide the teaching according to the students' professional characteristics. As an extension of the first class, the second class of ideological and political teaching is of great significance in ideological and political teaching, and is also a practical channel to test ideological and political theory teaching. In the second class of ideological and political education, it is necessary to integrate relevant educational contents of science, humanities and morality and reflect them in the forms of student associations, social practice platforms, campus cultural activities and party organization activities, so as to strengthen the connotation of ideological and political education and make it more suitable for practical activities. In the second class teaching of ideological and political education, colleges and universities should actively encourage and guide the extensive participation of students. Under the organization of teachers, colleges and universities should carry out various targeted practical activities, strengthen the knowledge and theories students have learned, and integrate into the cultivation process of correct moral values and outlook on life, promoting the overall improvement of students' comprehensive quality.

\subsection{Strengthen the teaching staff of ideological and political education in colleges and universities}

Colleges and universities should change the traditional mode of ideological and political education, enabling ideological and political education to be no longer promoted only by ideological and political theory teachers and 
class counselors. It is necessary to enable all staff members to participate in ideological and political education, so as to build a community of ideological and political education and promote the formation of a big pattern of ideological and political education teachers. Under the background of "great ideology and politics", teaching and ideological and political education are integrated. As a teacher, everyone bears the glorious mission of teaching and educating people. Educating in the so-called "teaching and educating" means ideological and political education work. Therefore, only with the concerted efforts of all educators can it reflect the huge strength of ideological and political education team. No matter ideological and political theory teachers or specialized course teachers, they should strive to become workers who actively practice ideological and political education. The teachers of the ideological and political theory class alone cannot afford the entire mission of ideological and political education, so teachers of professional courses need to integrate professional knowledge teaching into ideological and political education, shape the students the correct moral values, political thought, noble sentiment, promote the comprehensive quality of students, and play an important role of the professional course teachers in the ideological and political teaching. In addition, educators in colleges and universities should have a big picture view. They should not only earnestly perform their ideological and political teaching duties, but also have a forward-looking and cooperative attitude, and cultivate their ability to teach in different professional fields so as to further develop ideological and political teaching.

\subsection{Strengthen the integration and utilization of ideological and political education resources}

In order to carry out ideological and political education in colleges and universities comprehensively, it is necessary to strengthen the integration and utilization of teaching resources, adopt all-round ideological and political education through various ways and means, and make concerted efforts to develop together. Starting from the state and education departments, it is necessary to provide institutional basis, law and financial guarantee for ideological and political education in colleges and universities, play a supervisory role, strengthen the assessment and supervision mechanism, and actively promote the standardized development of ideological and political education system in colleges and universities; Starting from the social level, colleges and universities should make rational use of social education resources to strengthen ideological and political teaching of college students, cultivate and hone students through social practice, enabling them to combine professional knowledge and practical skills, be guided, increase their abilities and make contributions in social practice; Starting from the family level, students' good ideological sentiment, moral concept, political consciousness and good character are all derived from the family to some extent, and family education is the basic guarantee of ideological and political education; Starting from the school level, colleges and universities should create a good ideological and political education environment, establish a teaching network for all students to participate in ideological and political education, actively solve students' practical problems in study and life, and effectively coordinate resources at all levels, so as to achieve a harmonious and effective unity between school ideological and political education and national, social and family education.

\section{Conclusion}

In the perspective of "great ideology and politics", the ideological and political education in colleges and universities must have the big picture, based on the comprehensive development of students' comprehensive quality, combine the theoretical knowledge and practical teaching, establish the overall consciousness of "great ideology and politics", reform teaching methods, strengthen the construction of teaching staff, properly integrate and utilize teaching resources, and actually infiltrate the content of ideological and political education that truly fits the background of the era into every link of teaching, students' daily life and social practice, bring all forces together to form a joint force of ideological and political education to fully exert the role of ideological and political education in colleges and universities, and meet the needs of the national education to train comprehensive talents.

\section{References}

1. Wang Huanhuan. The Exploration of Ideological and Political Course Teaching in Higher Vocational Colleges from the Perspective of "Great Ideology and Politics" [J]. Comparative Research on Cultural Innovation,2017,1(32):29-30. 
2. Duan Jianhua. The Discussion on Ideological and Political Education in Colleges and Universities from the Perspective of Great Ideology and Politics [J]. Electronic Journal of New Education Time (Student Edition),2017, (9):155-156.

3. Zheng Hao. Ideological and Political Education Reform in Higher Vocational Colleges Based on "Great Ideological and Political Education" [J]. Wind of Science and Technology, 2020, (6):106.

4. Bao Xinyu. Ideological and Political Course Teaching Reform and Practice in Higher Vocational Colleges under the Pattern of "Great Ideology and Politics" [J]. Wind of Science and Technology,2019, (36):48. 